\title{
The Entrepreneurial Leadership of Headmaster in Realizing Achievement School: Case Study at Public Junior High School 1 Lamongan East Java Indonesia
}

\author{
Fathurrahman \\ Universitas Islam Lamongan, Indonesia \\ fath@unisla.ac.id
}

\author{
Asmoni \\ STKIP PGRI Sumenep, Indonesia \\ asmoni@stkippgrisumenep.ac.id
}

\author{
Achmad Sidi \\ STKIP PGRI Lamongan, Indonesia \\ ahmadsidi@stkippgrilamongan.ac.id
}

\begin{abstract}
This study focuses on the entrepreneurial leadership of headmaster in realizing achievement school, case study in Public Junior High School 1 Lamongan (SMP Negeri 1 Lamongan), researchers based their study on 5 (five) entrepreneurial competencies of principals as Permendiknas Number 13 of 2007 concerning School Principals Competency Standards. This study uses qualitative research methods, by collecting data through interviews, observation, and documentation. The results showed that the success of the application of entrepreneurial leadership of the headmaster of SMP Negeri 1 Lamongan, can be seen through the indicators of entrepreneurial leadership in realizing SMP Negeri 1 Lamongan to become an advanced and achieving school, as follows: (1) visionary; (2) innovative; (3) discipline; (4) hard workers; (5) committed; (6) responsible; (7) reliable motivator; (8) able to solve problems; (9) risk taking; and (10) have an entrepreneurial sense.
\end{abstract}

Keywords: entrepreneurial leadership, headmaster, achievement school

\section{INTRODUCTION}

The principals as the education leader who is responsible for school leadership, where in the study of Soemanto and Soetopo (1982) it is said that school leadership is an action or behavior among individuals and groups that causes them to move towards achieving school goals that add shared acceptance for them. Referring to the characteristics of leadership can be translated into terms: traits, personal behavior, influence on others, patterns of interaction, cooperative relationships between roles, position of an administrative position, and perceptions of others about the legitimacy of influence. Wahjosumidjo (2002) further explained that leadership as an activity influencing people to work together leads to the achievement of the goals they want. Therefore, as a key element for the progress of the school, the principal has a major contribution to the progress and withdrawal of the school, the competent headmaster has a significant impact on the progress of the school.

The key role of the headmaster in making the school successful is alluded to by Sergiovanni (2007) which states the key for school success is principal". The key to school success is to depend on the headmaster. Schools can run effectively when lead by a great headmaster who is characterized by having a strong vision, hard work, able to create an atmosphere of discipline, cooperation, responsibility, and motivate teacher development. On the other hand, headmasters who are inadequate can certainly not be able to bring schools to develop and advance. A principal, according to Arifin (2008) has five functions of accountability, namely: (1) the safety, welfare, and development of students in the school environment; (2) the welfare and professional success of the teachers; (3) full service that is valuable to students and teachers that may be done through other official supervision; (4) get maximum assistance from all supporting institutions; and 5) promoting the best students through various means.

The noble lesson about the leadership of the headmaster was taught by Ki Hajar Dewantara, the first Minister of Education of the Republic of Indonesia: ing ngarso sun tuladha, ing madyo mangun karso, tut wuri handayani (in the front became a role model, amid fostering abilities, behind being a motivator). The headmaster must be able to be an example to his subordinates, inspire, be able to work with subordinates in realizing his program vision, and can also motivate his subordinates to work diligently and passionately. The importance of leadership roles and functions has become one of the themes that attract. The expert is to be studied and is a process that touches directly into human life (Yukl, 1981).

In order to meet the needs of advanced schools, headmasters need several competencies that need to be mastered. Fathurrahman (2014) stated that the competencies possessed by principals influence the existence of healthy and dynamic schools. The competence of headmasters requires competency tools that need to be mastered. Mintzberg divides the principals' competence in carrying out managerial technical tasks into three categories, namely: (1) impersonal, the task of the headmaster in carrying out functions as a figure, leader and negotiator; (2) informational, the task of the headmaster 1 in carrying out functions as a monitor, disseminator, and intermediary; and (3) decisional, the duty of the headmaster in carrying out functions as an entrepreneur, allocator of resources, and negotiator (Danim, 2002). 
Meanwhile, as regulated in Ministry of National Education's Regulation number 13 of 2007 concerning the competency standards of headmaster / madrasah, it specifies special qualification standards in the form of five competencies that must be possessed by the principal, namely: personality competency, managerial competence, entrepreneurial competence, supervision competence, and social competence.

Entrepreneurial competencies that must be possessed by the headmaster as Permendiknas Number 13 of 2007 explains that the principal's entrepreneurship competency is marked by: (1) create innovations that are useful for school/madrasah development; (2) work hard to achieve school success as an effective learning organization; (3) have a strong motivation to succeed in carrying out basic tasks and functions as school leaders; (4) never give up and always look for the best solutions in the face of obstacles faced by schools; and (5) have an entrepreneurial instinct in managing school production/service activities as a learning resource for students.

Entrepreneurial competencies of headmasters are closely related to the characteristics and leadership style of headmasters in managing schools to be more advanced and competitive. Leadership related to entrepreneurship competency is important to be owned by the principal because this competence is able to provide superior and potential school performance. Through competence in entrepreneurship, headmasters can carry out various creativities and innovations to develop schools to respond to the demands of community needs (students and teachers as well as the user community in general).

Entrepreneurial leadership is a leadership that can encourage dynamic organization, innovative and empowering organizations through learning that occurs from the stage of the individual, group to organization. The key factor is that headmasters play an optimal role and can apply entrepreneurial headmaster in managing school organizations to achieve educational success in schools. With the entrepreneurial leadership, a headmaster will be able to develop the organization towards a more innovative way through increasing creativity, trust and cooperation with the community. Entrepreneurial leaders are proactive leaders in finding and utilizing opportunities to achieve success. Characteristics of entrepreneurial leadership are characterized by having a strong vision, oriented towards the future that is dominant and adaptive to various changes and situations in the school environment.

\section{METHODS}

The design of this study uses a qualitative approach, namely research procedures that produce descriptive data in the form of speech or writing and behavior that can be observed from the people or the subject itself. The presence of researchers as a key instrument to give meaning of the phenomenon clearly and act actively in the entire study process. The object of this research was chosen at SMP Negeri 1 Lamongan, the oldest school in the city of Lamongan with many proud achievements for the world of education and Lamongan regency, with a focus of studies on the headmaster's entrepreneurial leadership.

Data collection is done by participant observation techniques, in-depth interviews (in-depth interviewing), and study of documents. Data analysis is an activity to find and systematically compile data obtained from field notes, interviews, and other materials, so that the findings can be understood and informed to others. Researchers carry out the process of interpreting and concluding data. Next, the validity of the data was tested through triangulation techniques.

\section{RESULTS}

Based on data in the field, the headmaster has had entrepreneurial competencies and has carried out entrepreneurial character leadership practices that have proven to be able to bring SMP Negeri 1 Lamongan into an advanced and outstanding school. In detail can be stated in the following Table 1. Entrepreneurship competency of the principal and the character of entrepreneurial leadership carried out by the head of SMP Negeri 1 Lamongan.

Table 1

Entrepreneurship Competency of the Principal

\begin{tabular}{|ll|ll|}
\hline Headmaster entrepreneurial competence & \multicolumn{2}{l|}{$\begin{array}{l}\text { Character of headmaster entrepreneurial leadership of } \\
\text { Permendiknas Number 13 in } 2007\end{array}$} & SMP Negeri 1 Lamongan \\
\hline 1. & Creating innovations that are useful for schools & 1. & Visionary \\
2. & Work hard to achieve school success as an effective & 2. & Innovative \\
learning organization & 3. & Discipline \\
3. Has a strong motivation to succeed in carrying out its & 4. & Hard workers \\
main tasks and functions as a school leader & 5. & Committed \\
4. To surrender and always look for the best solution to & 6. & Responsible \\
the obstacles faced by the school & 7. & Reliable motivator \\
5. Have an entrepreneurial instinct in managing school & 8. & Able to solve problems \\
production/service activities as a learning resource for & 9. & Risk taking \\
students & 10. & Have an entrepreneurial instinct \\
\hline
\end{tabular}

\section{DISCUSSION}

General situation from the leadership behavior that it has been existed at the State Junior High School 1 of Lamongan resembling the working situation of Fiedler's contingent leadership model as Daff \& Steers (1989) stated the group performance was determined on the leadership style and the natural situation of leadership. Visionary and innovative character revealed the efforts in building the school more inventive by the principal of the State Junior High School 1 of Lamongan. The visionary principal of the school has asked all the school's stakeholders to have vision, to 
contribute courage through visionary ideas, to have involvement, planning and settling the hopes for more ideal school. In relation to these, visions and innovations are required to implement ideas in increasing the school's performance as Abdurrahman Wahid's representation about social leadership (Horikosi, 1987) where behind the stillness of religious institutions, yet there would be their leaders who capable of formulating some new ideas in order to bring the changes on social life.

Referring to discipline, hard-working and motivating in team-works is about how the principals build some encouraging cultures and create some supporting atmospheres that those support the team's works. Dubrin (2005) stated that the team-work was the essential competence to perform success. The activities need efforts in building apt cultures to motivate people. The strategies that were suggested include promoting people to cooperate effectively as standardized attitudes expected. In relation to discipline and commitment, Maxwell (1999) stated that each time a leader making choices based on the solid living principles so he/she would place himself/herself on better situation to preserve the commitment level. The affiliation of a leader's principles and the competences of his/her adherent would be interconnected in accomplishing the leader's commitments.

Pozner (2004) countered to the responsibilities from a leader that a leader has responsibility in growing the transparency, the involvement, the personal satisfaction, and the highly commitment to the best results or achievements. Courageous character in taking risks and the capable character of problem solving have been put on view by the principal of the State Junior High School 1 of Lamongan. Under the principal's directions, the teachers were capable of doing many things in solving the problems and increasing their creativity on learning activities since these required the advanced supports from the principal. The principal has capability in constructing the expectancy on creativity into learning activities at school and the learning strategies to be conducted by the teachers. These enhanced the teachers to gain their abilities in solving the learning problems. Therefore, the teachers could motivate, recognize and contribute solutions to the other teachers and students. The principal has capability of providing resources on creative efforts which involve the teachers and the students in constructing environmental stimulus, challenging the creativity from the teachers, the students, the parents and the community.

The principal with entrepreneurship could be deduced that the entrepreneurship competences in running the school leadership was line up with the economic principles and the industrial world not only to encounter the challenges from the schooling environmental changes but also to give directions on creating more inventive school. As the regulation from The Indonesian Ministries of Education Number 13 Year 2007 (Permendiknas Nomor 13 Year 2007) stated about the principal's standard competences that it regulated the principal to cope with the entrepreneurship competence as one of requirement in charge of the principal position. Entrepreneurial leadership from a principal could be able to develop his organization to more innovative directions through the increasing creativity, contribution, trust and cooperation with the community.

Entrepreneurial leadership is a proactive leader in seeking for and utilizing opportunities to achieve the success and adaptive leader in encountering a set of environmental changes and a leader whose dominant orientation to the future. Caldwell and Spinks (1992), in relation to the context of the current schooling organization, viewed that every schools need an entrepreneurial leader as "An appraisal of current context of schooling suggests that entrepreneurial schools and entrepreneurial leaders are precisely what are called for original meaning of entrepreneurship, one which emphasizes creativity, confidence and an enduring contribution to the community."

Associated with the entrepreneurial leadership of the principal at SMP Negeri 1 Lamongan East Java, which was run by Drs. H. Khoirul Anam, M.Pd. can be seen in the success of the school to get TOPTEN Achievement that is proud of the world of education in Lamongan district, especially for SMP Negeri 1 Lamongan. Ten achievements achieved by the school during his seven years of leadership were: (1) a pilot public service unit in the field of education, 2012 East Java Governor Award; (2) an ISO 9001: 2008 school from Bureau Verities Jakarta since 2012; (3) Widya Pakarti Nugraha School, 2014 East Java Governor Award; (4) National Adiwiyata School, 2014 LH \& K Minister Award; (5) the national pioneer UNBK school; (6) schools with integrity, Minister of Education and Culture Award 2015; (7) a school with an a library license, an award from the National Library in 2016; (8) National Quality Reference school, SK 2016 Director of PSMP; (9) schools with the best national quality governance, the Minister of Education and Culture Award 2017; and (10) character schools, Minister of Education and Culture Award 2017.

\section{CONCLUSION}

The results of the study described above can be concluded that the headmaster of SMP Negeri 1 Lamongan has fulfilled the requirements of the entrepreneurial competency of the headmaster and is able to run it well as stated in Permendiknas Number 13 of 2007 concerning the headmaster competency standards.

The success of the implementation of entrepreneurial leadership of the head of SMP Negeri 1 Lamongan can be expressed as having several characteristics of entrepreneurial leadership indicators in realizing achievement schools as follows: (1) visionary; (2) innovative; (3) discipline; (4) hard workers; (5) committed; (6) responsible; (7) reliable motivator; (8) able to solve problems; (9) risk taking; and (10) have an entrepreneurial sense. The ten traits and characteristics of the entrepreneurial leadership of the school principal were proven to be able to realize the Lamongan 1 Public Middle School to become an advanced and achieving school. 


\section{REFERENCES}

[1] Arifin, I. 2008. Kepemimpinan Kepala Sekolah dalam mengelola Sekolah Berprestasi. Yogyakarta: Aditya Media.

[2] Caldwell, B. J., and Spinks, M. 1998. Beyond The Self Managing School. London: The Falmer Press.

[3] Danin, S. 2002. Inovasi Pendidikan dalam Upaya Peningkatan Profesional Tenaga Kependidikan, Bandung: Pustaka Setia.

[4] Dubrin, A. J. 2005. Leadership. Jakarta: Prenada Media.

[5] Fahurrahman. 2014. Kepemimpinan Kepala Sekolah sebagai Supervisor Pembelajaran. Jurnal Studi Islam Akademika, 8(1).

[6] Maxwell, J. 1999. Be a People Person. Batam: Interaksara.

[7] Posner, K. 2004 Leadership Challenge. Jakarta: Erlangga.

[8] Rini, W. A. 2004. Efffective Leadership and Teaching Organization: Suatu Pendekatan Sikap dan Perilaku. Kindai - Jurnal Ilmiah Manajemen dan Akuntansi, $1(1)$.

[9] Sergiovanni, T. J. 2007. The Principalship: A Reflective Practice Perspective. Boston: Allyn \& Bacon.

[10] Soemarsono, H. 2003 Teamwork Plus. Jakarta: LLB.

[11] Soemanto, W., and Soetopo, H. 1982.Kepemimpinan dalam Pendidikan. Surabaya: Usaha Nasional.

[12] Sumidjo, W. 2002. Kepemimpinan Kepala Sekolah (Tinjauan Teoritik dan Permasalahannya). Jakarta: PT Raja Grafindo Persada.

[13] Yukl, G. A. 1981. Leadership in Organization. Englewood Cliffs, N.J.: Prentice-Hall. 